\title{
Is the Global Food Supply Chain during the COVID-19 Pandemic Resilient? A Review Paper
}

\author{
Yasir A. Nasereldin 1,2, Robert Brenya1, Anthony Pius Bassey³, Ibrahim Elnour Ibrahim², \\ Fawze Alnadari ${ }^{3}$, Mustapha Muhammad Nasiru', Yueqing Ji ${ }^{4}$ \\ ${ }^{1}$ College of Economics and Management, Nanjing Agricultural University, Nanjing, China \\ ${ }^{2}$ Department of Agricultural Economics and Agribusiness, Faculty of Natural Resources and Environmental Studies, Kordofan \\ University, El Obied, Sudan \\ ${ }^{3}$ Department of Food Science and Engineering, College of Food Science and Technology, Nanjing Agricultural University, \\ Nanjing, China \\ ${ }^{4}$ Department of Food Science and Technology, Federal University, Dutsin-Ma, Katsina State, Nigeria \\ Email: *jyq@njau.edu.cn
}

How to cite this paper: Nasereldin, Y. A., Brenya, R., Bassey, A. P., Ibrahim, I. E., Alnadari, F., Nasiru, M. M., \& Ji, Y. Q. (2021). Is the Global Food Supply Chain during the COVID-19 Pandemic Resilient? A Review Paper. Open Journal of Business and Management, 9, 184-195.

https://doi.org/10.4236/ojbm.2021.91010

Received: December 1, 2020

Accepted: January 5, 2021

Published: January 8, 2021

Copyright $\odot 2021$ by author(s) and Scientific Research Publishing Inc. This work is licensed under the Creative Commons Attribution International License (CC BY 4.0).

http://creativecommons.org/licenses/by/4.0/

\begin{abstract}
The Coronavirus outbreak has brought a global health emergency with a newfound domestic and international trade disruption such as restrictions on imports and exports of major food commodities, loss of lives, closure of various essential institutions, and the likes. With the spread of COVID-19 around the world, the food and agricultural sector have experienced a negative downturn with an immense labor loss, inadequate distribution of food inputs around the world. Thus, the question arises that to what extent can the food supply chain remain resilient to the effects of the pandemic? And, what are the immediate and lasting resolutions? Importantly, the resilience of the food supply chain is critical to mankind's survival. In this paper, we highlighted the main challenges faced by the resilience of the global food supply chain. We also present policies and suggestions that focus on mitigating the impact of the pandemic on food production and distribution systems.
\end{abstract}

\section{Keywords}

COVID-19, Emerging Challenges, Food Supply Chain, Resilience, Pandemic

\section{Introduction}

COVID-19 is a viral respiratory illness caused by a new strain of coronavirus. It was erupted in Wuhan, China in December 2019 and reached a pandemic state 
(Butler and Barrientos, 2020), in February 2020, and has since become a major worldwide human menace (Celik and Dane, 2020; Naja and Hamadeh, 2020). Following its declaration as a Public Health Emergency of International Concern by the World Health Organization (WHO) (Guan et al., 2020; Kapata et al., 2020), the global spread of the outbreak has caused over 26 million cases and 874,157 deaths worldwide as at September, $26^{\text {th }}$ (WHO, 2020). To curb the rapid spread, many countries enforced lockdown rules which have led to a deficiency in the labor force, logistics uncertainties, and turmoil in the food supply chain (Hobbs, 2020). These have posed significant risks to food security and nutrition of millions of people worldwide, majority of which were already experiencing famine and malnutrition. Unless immediate action is taken, a global food emergency will occur (Amjath-Babu et al., 2020; OECD, 2020a; United Nations, 2020a). Moreover, international relationships have gone far beyond the agri-food sector's labor force (Stephens et al., 2020).

Food production requires the use of inputs such as seeds and fertilizers (OECD, 2020b). However, there are difficulties in international shipping, cross-border, and movement restrictions in various countries (Devereux et al., 2020). Universally, food production and consumption are gaining more attention with anxiety in production compared to the worldwide demand for food (de Paulo Farias and de Araújo, 2020). Additionally, the COVID-19 pandemic has endangered the production chain and has put nations on high alert for a possible food supply disaster in the world. Food supply chains in developing countries have been greatly affected, inadequate health services, labor-intensive agriculture, logistic ambiguity, among others (OECD, 2020b). According to Ivanov and Dolgui (2020), the supply chain from every angle has been affected, especially the chains of fresh vegetables, fruits, bakery items, perishable goods, and food grains. Major disturbances in the food supply chain triggered by the coronavirus pandemic have worsened the acute glitches of starvation, malnutrition, and food waste (Lal, 2020). Vulnerable food-dependent developing countries are expected to experience the ugliest impact of food supply disruptions, particularly in the area of cereals, meat, and fresh fruit, etc. (Espitia et al., 2020).

\section{Food Supply Chain and COVID-19}

According to (Gereffi, 2020), global supply chains have rapidly become a new slogan in public awareness. Liu (2020) introduced a commentary on COVID-19 and the food system and reported that food supply has been disrupted by COVID-19. Updates by mainstream media showcasing the inadequacy of food access during the pandemic (Bakalis et al., 2020) have triggered incessant worries, thereby causing superstores and grocery stores to be out of products due to panic buying. Notably, all sectors are connected through a network of supply chains and logistics (Figure 1). The pictorial diagram demonstrates the chain to which food from the farm ends on the table. This chain includes the connection of raw materials by producers, processors, distributors and consumers. Thus, a 


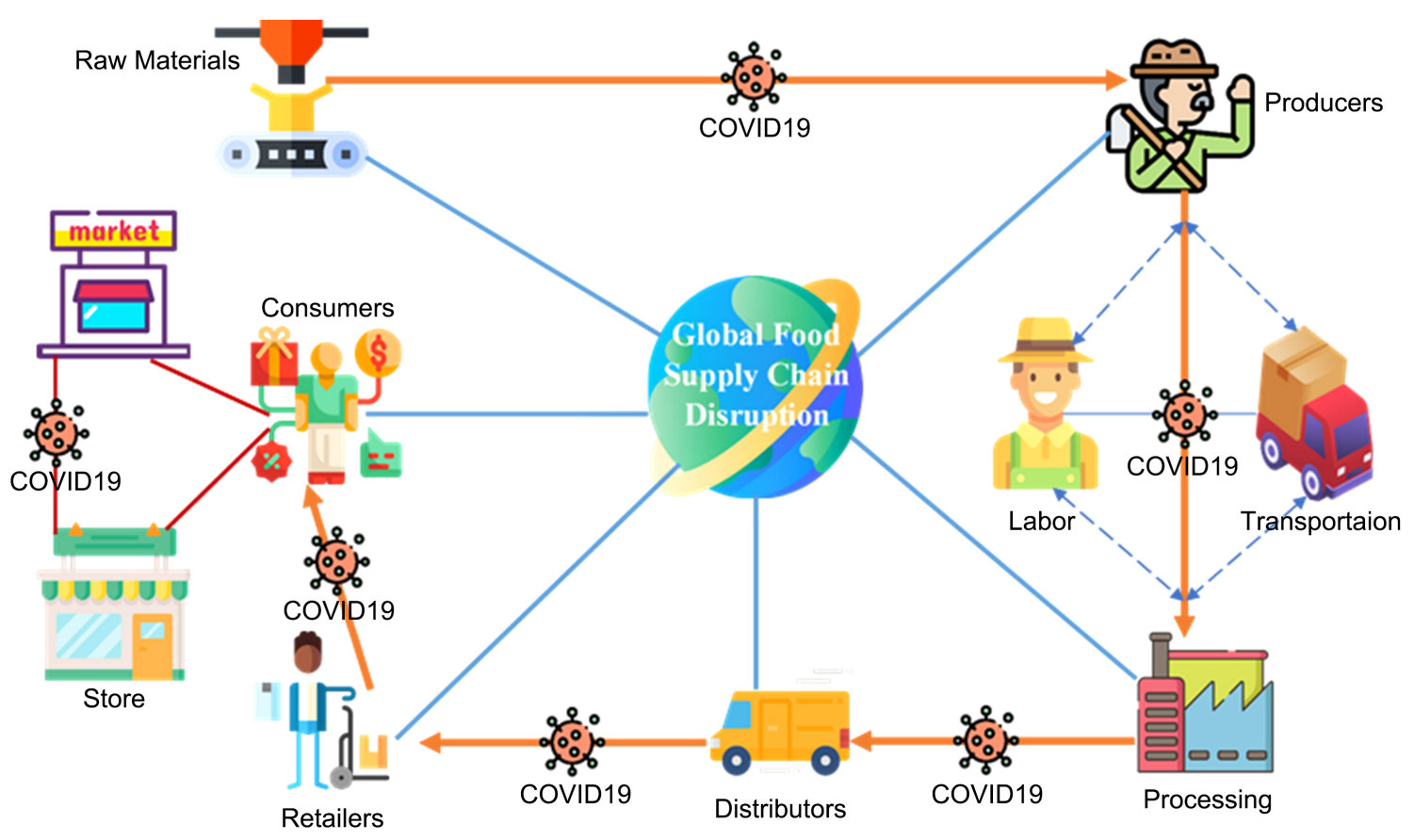

Figure 1. The global food supply chain disrupted by COVID-19.

disruption in one of these constitutes a negative effect on the other. For example, the emergence of the COVID-19 pandemic shrunk the global manufacturing output by 20 percent in April 2020 compared to the same period of the previous year, thereby accelerating an already declining trend (Me \& Fu, 2020). The World Bank, International Monetary Fund, and the World Economic Forum have indicated a probable economic recession due to a rapid decline in economic activities (Singh et al., 2020). Lockdown measures affected different supply chains, leading to lower economic growth or an expected economic recession. Recent reports and observations in world economies have evidenced a rapid deterioration of several businesses and economic indicators, including global GDP as a result of the pandemic. Although the Coronavirus was first reported in East Asia (China), the impact is mostly felt in Sub-Saharan Africa already troubled with food insecurities, poor infrastructures and economic decline (Figure 2). Deep global economic shocks caused by COVID-19 will impact the cash flow and financial liquidity of producers, small and medium agri-businesses to financial institutions, due to inhibited production capacity, limited market access, loss of remittances, lack of employment, and unexpected medical costs (United Nations, 2020b). Importantly, food supply chains are not exempted from these turbulences. In fact, since the beginning of the pandemic, the coronavirus has transformed dramatically in terms of availability to food, food accessibility, food loss, and waste (Aldaco et al., 2020).

Agricultural production has been affected by bottlenecks in inputs, particularly employment. Some agricultural sectors are more dependent on periodic employment than others, and restrictions on people's movement have limited 


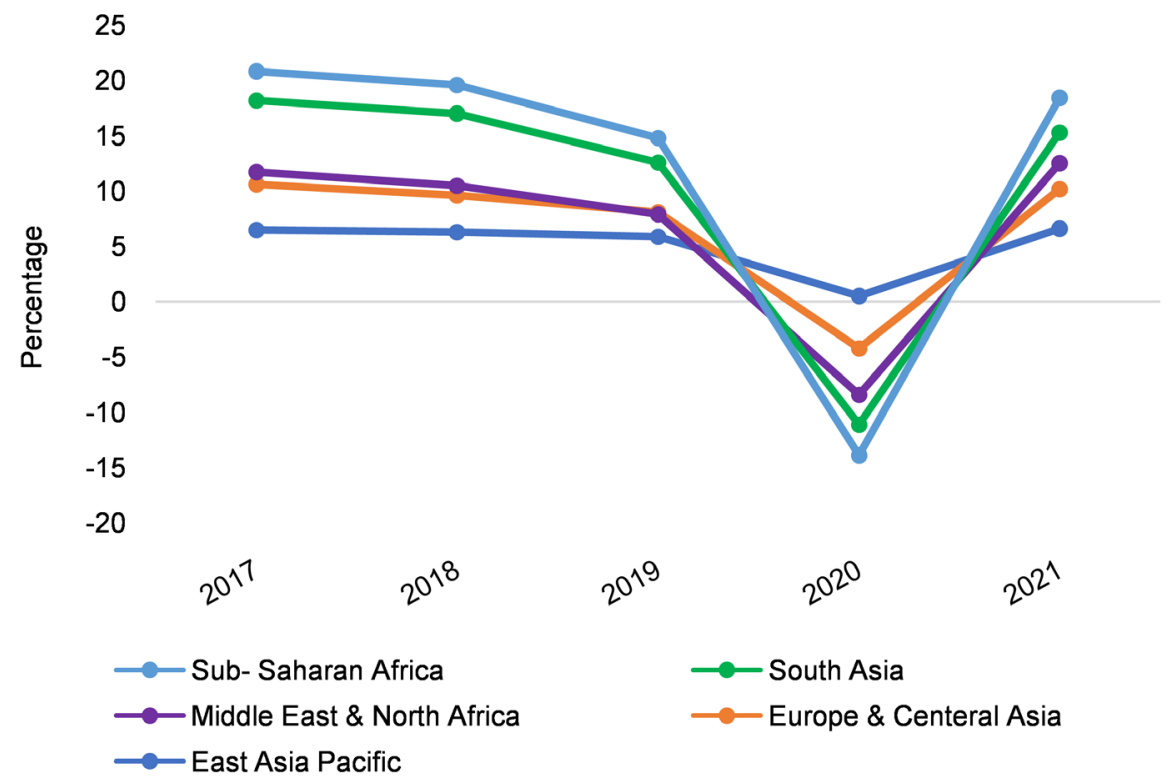

Figure 2. The impact of COVID-19 on gross domestic product. source (World Bank, 2020a).

access to seasonal labor for planting and harvesting in the vegetable and fruit sector in numerous countries (OECD, 2020b; Poudel et al., 2020). Recent agricultural performance and urbanization across the world have resulted in a complex food supply chain, frequently requiring long transportation of raw materials including staple food commodities such as maize, wheat, soybeans, corn, and oilseeds, as well as causing sustainable environmental challenges in addition to worsening in quality (Bakalis et al., 2020). From the onset of the supply chain, every part can experience disruptions, starting from the farmer to consumer (Deaton and Deaton, 2020). The implications of coronavirus on the food supply chains have been so grave on the least developing countries more than anywhere else (Udmale et al., 2020).

\section{Supply Chain Resilience}

Supply chain resilience is an adaptive capability that enables the preparation for unforeseen events, how to recuperate from breakdowns, and continue operations as expected (Chowdhury and Quaddus, 2017; Simba et al., 2017; Darren Briggs, 2019). Resilience is presently increasing the anxiety in the supply chain. To this effect, Pires Ribeiro and Barbosa-Povoa (2018) cautioned the ability to use effective means to support resilient supply chain decisions. Folke (2006) explained the need for suppleness and adaptability, as well as market absorption and ecological shocks leading to an operative food supply chain. One of the biggest challenges to the crisis is the development of food systems that are sufficiently resilient to continue operations. The term food system resilience has been introduced by (Bakalis et al., 2020; Tendall et al., 2015) as the capacity overtime of a food system and its units at multiple levels, sufficient provision, appropriate 
and accessible food to all even during uncertainties. During this pandemic, most decision-makers concentrate on the steadfastness of the supply chain, especially its adaptability in providing what is demanded in the frequent food purchasing style (Hobbs, 2020). Golan et al. (2020); Ivanov and Dolgui (2020) evidenced the impact of COVID-19 on the food supply chain and indicated that the pandemic rate of impact is unparalleled to the global supply chain's resilience. They also postulated the supply chain's ability to absorb and withstand difficulties, is essential to safeguard its performance and success.

\section{Emerging Challenges}

The COVID-19 came at a time when food and food security systems were already under stress. Conflicts, natural disasters, climate change, intercontinental pest, and plague arrivals preempt the pandemic, and they are already undermining food security in many contexts (United Nations, 2020a). For instance, in East Africa, people are facing a "triple menace" of mutually exacerbating disasters, as ongoing heavy rain hampers attempts to deal with swarms of locusts in the midst of the COVID-19 outbreak (IFRC, 2020a). Meanwhile, the worst locust crisis in decades threatens crops heading into the harvest period as experienced recently in Kenya (IFRC, 2020b).

As well as the delay in vaccine development and the remoteness of clinical treatment has worsened the situation. The pandemic has put unexpected pressure on food systems, creating many immediate challenges. What is remarkable, is the rate at which supply chain actors have been able to reorganize themselves to ensure the continued availability of food in the least developed countries. However, there are still some bottlenecks, and some new disturbances may appear as COVID-19 continues to spread (OECD, 2020b). One of the main challenges shaped by the coronavirus pandemic is the difficulties for urban dwellers to access fresh and nutritious food and at affordable prices. The situation is exacerbated by a lack of infrastructure and weak institutional support (Lal, 2020). Also, the pandemic has the potential to affect the smooth transport function among the stages of the food supply chain.

COVID-19-related diseases have limited the availability of skilled personnel in the transportation sector along the food supply chain. (Deaton and Deaton, 2020) elaborated that, the supply chain includes inputs in the field, storage, manufacturers, distributors, and retailers. Since one-third of the world's population is on lockdown, global food security warnings have emerged. The outbreak has aggravated boundless food uncertainty worldwide and threatens to create long-term malnutrition and bad health consequences (Zimmerer and de Haan, 2020). At the community level, the availability and access to food have worsened due to difficulties in transportation, distribution, and delivery. Many lockdowns have resulted in an unwanted consumer disturbance because of inadequate market supply (Heck et al., 2020). Consumer behaviors have also changed (Naja and Hamadeh, 2020) with an overwhelming impact on the food system (Ragasa 
and Lambrecht, 2020). The World Food Crisis Report estimates that 135 million people were food insecure in 2019. However, recent World Food Programme (WFP) projections indicate that, due to economic impacts and disruption of the supply chain associated with COVID-19, this number could double in 2020 to 265 million (Hailu, 2020).

Millions of people affected by the COVID-19 crisis are not as a result of the virus itself (infection, disease, or death), but from loss of income and purchasing power, associated with the closure of institutions imposed by national/local governments (Béné, 2020). The Organization for Economic Cooperation and Development (OECD) and the Food and Agriculture Organization (FAO) have developed a scenario that explains how the COVID-19 pandemic could lead to a historically significant market shock. In this scenario, agricultural prices including food, raw materials and beverages, fell sharply in response to the COVID-19 reduction in disposable income, particularly in low-income countries (Figure 3). The figure describes the effect of the pandemic on the decline of agricultural prices following the disruption in the supply chain from food production to distribution channels, resulting in consumers demanding less as observed during the lockdown period globally. This also resulted in food glut where farmers in lower income countries lack storage facilities to extend the shelf life of their produce. As also reported, this unprecedented loss of purchasing power, consumer consumption of food will decline despite lower corresponding prices (OECD \& FAO, 2020). Before the pandemic, extreme weather conditions among other factors have already been plaguing food security in the Middle East and Northern Africa, Sub-Saharan Africa, Latin America, and South Asia (Figure 4). Unfortunately, the ongoing economic crises in Venezuela, Haiti, Sudan, and Zimbabwe have affected food security in those countries. More so, about 71 to 100 million people have been pushed into extreme poverty with South Asia and sub-Saharan Africa prone to the hardest hit (Me \& Fu, 2020; Udmale et al., 2020).

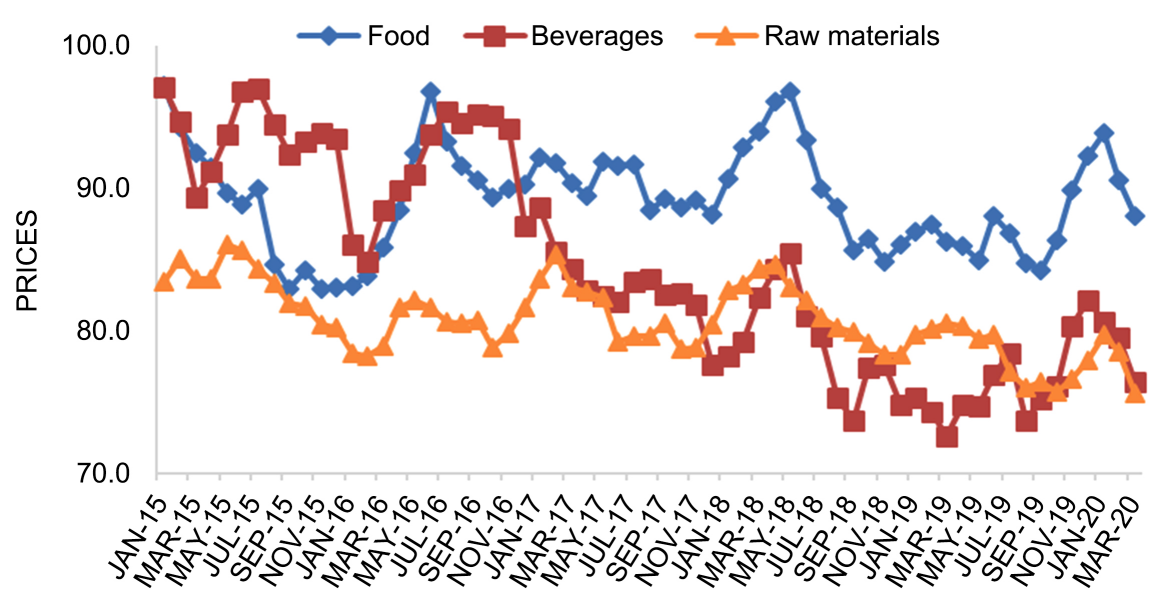

Figure 3. Monthly agricultural prices indices of food, beverage and raw materials. Source (World Bank Group, 2020). 


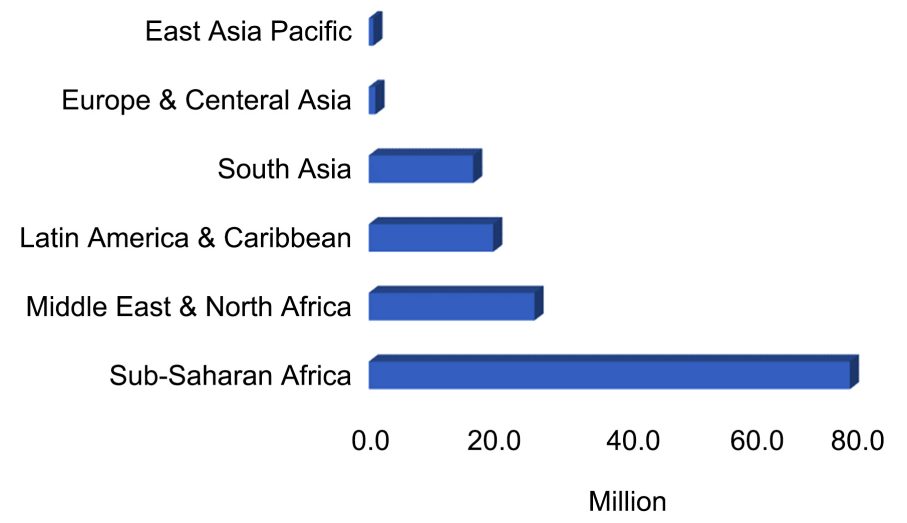

Figure 4. People in the food crisis by region in 2019 (before COVID-19). Source (World Bank, 2020b).

\section{Solutions and Suggestions}

Enhancing the resilience of the global food supply requires everybody in the supply chain to understand the intricacies of the system to be able to respond to and recover from unforeseen events (Darren Briggs, 2019). To avoid massive food shortages, countries must maintain food supply chains. In line with this, FAO proposes specific strategies, such as expanding emergency food assistance programs and providing immediate assistance to small agricultural production farmers' via e-commerce promotion (Galanakis, 2020). The food supply system will also need to consider items that can be stored and be refurbished safely. More so, the mobilization of food banks, NGOs, community groups, and private food charities (with families staying at home) during the closure period can also help in this direction (Galanakis, 2020). Furthermore, there is a need for more robust balanced diets while reducing food waste along the supply chain and promoting the growth of local agricultural capacity through home gardening and urban farming (Lal, 2020). Strengthening storage, processing, and distribution of food commodities is also vital in mitigating the food and nutrition insecurity during the current crisis (Farrell et al., 2020).

Additionally, farmers need assistance to boost their productivity and facilitation of the products (Lawson-Lartego and Cohen, 2020), for instance, through e-commerce networks. Effective execution of short food supply chains during lockdown can provide a supplementary mechanism to address food resilience, (Bakalis et al., 2020). Importantly, policymakers need to also carefully consider the comprehensive consequences of export control measures and restrictions in regional cross-border trade. In the short term (the next 12 months), farmers need to reliably obtain seeds and other production inputs to ensure the food security of their families (Heck et al., 2020), and further provide short-term support to producers in a way that ensures that optimum productivity is maintained. The representatives of countries in the food chain should help deal with short- and medium-term challenges without compromising long-term policy objectives (OECD, 2020a). For example, some EU governments are already 
supporting farmers, and fruit and vegetable traders by implementing ad-hoc measures that block work maintenance; tax relief and reduction of fines; and temporary credit facilities to accommodate the liquidity problems related to the coronavirus crisis (European Parliament, 2020). To facilitate these measures, on 15 April, Parliament's agriculture committee welcomed the Commission's plans to help the agri-food sector with more targeted action such as provision of private storage, activation of the crisis reserve to help struggling agricultural sectors to ensure adequate long-term budget support in the post-COVID period. The provision of more flexible and simplified European agriculture reallocation of unused agriculture funds to fight the effects of the crisis in rural areas through access to loans or guarantees at favourable conditions at very low interest rates or favourable payment schedules to cover operational costs of up to $€ 200,000$. Furthermore, on 19 June, Members of European Parliaments (MEPs) increased the crisis support for worst-hit farmers and small and medium-sized enterprises in EU countries dealing with farm food from the EU rural development fund. Farmers and small farm food companies could receive up to $€ 7000$ and $€ 50,000$, respectively. However, exchange information exchange to ensure smooth passage will be provided to seasonal workers who are crucial for planting, tending and harvesting (European Parliament, 2020).

\section{Conclusion}

As it is uncertain the end of the pandemic, coronavirus continues to threaten people's lives and the global economy. Until a vaccine is developed, the bearing of COVID-19 continues to be felt among the people. Despite the drop in prices of agricultural commodities, the spread of COVID-19 continues to threaten the global food supply chain with the disruption on the economy sectors, extreme constraint in the access of food, shortage of farm labor, fear of moving from one place to another, among other constraints. Although many countries have adopted policies to reduce the impacts of the pandemic on the performance of the food supply chain, significant problems still exist. Numerous studies bring out ideas that can directly or indirectly contribute to mitigating the damage caused to the supply chain (e.g., the EU commitment to support producers with production inputs, and other essential materials). Nonetheless, it is generally accepted that the coronavirus implications will have both short- and long-term effects especially developing countries suffering from extreme poverty, food crisis, diseases, etc. In this regard, FAO and IFAD are on the mission to find an urgent plan to assist troubling nations. The authors also believe that more studies are needed that need to focus on, how to enhance the resilience of smallholder's farmer to recover, especially in developing countries, as well as how to guide food systems to be more sustainable and resilient to future disasters.

\section{Acknowledgements}

The authors recognize Prof. Xu Tian for his suggestions and guidance. 


\section{Conflicts of Interest}

The authors declare no conflicts of interest regarding the publication of this paper.

\section{References}

Aldaco, R., Hoehn, D., Laso, J., Margallo, M., Ruiz-Salmón, J., Cristobal, J. et al. (2020). Food Waste Management during the COVID-19 Outbreak: A Holistic Climate, Economic and Nutritional Approach. Science of the Total Environment, 742, Article ID: 140524. https://doi.org/10.1016/j.scitotenv.2020.140524

Amjath-Babu, T. S., Krupnik, T. J., Thilsted, S. H., \& McDonald, A. J. (2020). Key Indicators for Monitoring Food System Disruptions Caused by the COVID-19 Pandemic: Insights from Bangladesh towards Effective Response. Food Security, 12, 761-768. https://doi.org/10.1007/s12571-020-01083-2

Bakalis, S., Valdramidis, V. P., Argyropoulos, D., Ahrne, L., Chen, J., Cullen, P. J. et al. (2020). Perspectives from CO+RE: How COVID-19 Changed Our Food Systems and Food Security Paradigms. Current Research in Food Science, 3, 166-172. https://doi.org/10.1016/j.crfs.2020.05.003

Béné, C. (2020). Resilience of Local Food Systems and Links to Food Security-A Review of Some Important Concepts in the Context of COVID-19 and Other Shocks. Food Security, 12, 805-822. https://doi.org/10.1007/s12571-020-01076-1

Butler, M. J., \& Barrientos, R. M. (2020). The Impact of Nutrition on COVID-19 Susceptibility and Long-Term Consequences. Brain, Behavior, and Immunity, 87, 53-54. https://doi.org/10.1016/j.bbi.2020.04.040

Celik, B., \& Dane, S. (2020). The Effects of COVID-19 Pandemic Outbreak on Food Consumption Preferences and Their Causes. Journal of Research in Medical and Dental Science, 8, 176-180.

Chowdhury, M. M. H., \& Quaddus, M. (2017). Supply Chain Resilience: Conceptualization and Scale Development Using Dynamic Capability Theory. International Journal of Production Economics, 188, 185-204. https://doi.org/10.1016/j.ijpe.2017.03.020

Darren Briggs, G. S. G. de V. (2019). Resilience of Global Food Supply Chains. In Arup and Resilience Shift, $U K$.

de Paulo Farias, D., \& de Araújo, F. F. (2020). Will COVID-19 Affect Food Supply in Distribution Centers of Brazilian Regions Affected by the Pandemic? Trends in Food Science and Technology, 103, 361-366. https://doi.org/10.1016/j.tifs.2020.05.023

Deaton, B. J., \& Deaton, B. J. (2020). Food Security and Canada's Agricultural System Challenged by COVID-19. Canadian Journal of Agricultural Economics, 68, 143-149. https://doi.org/10.1111/cjag.12227

Devereux, S., Béné, C., \& Hoddinott, J. (2020). Conceptualising COVID-19's Impacts on Household Food Security. Food Security, 12, 769-772. https://doi.org/10.1007/s12571-020-01085-0

Espitia, A., Rocha, N., \& Ruta, M. (2020). Covid-19 and Food Protectionism : The Impact of the Pandemic and Export Restrictions on World Food Markets. https://doi.org/10.1596/1813-9450-9253

European Parliament (2020). Covid-19: Emergency Measures to Help EU Farmers and Fishermen (pp. 1-3). News, European Parliament.

https://www.europarl.europa.eu/news/en/headlines/society/20200416STO77203/covid19-emergency-measures-to-help-eu-farmers-and-fishermen 
Farrell, P., Thow, A. M., Wate, J. T., Nonga, N., Vatucawaqa, P., Brewer, T. et al. (2020). COVID-19 and Pacific Food System Resilience: Opportunities to Build a Robust Response. Food Security, 12, 783-791. https://doi.org/10.1007/s12571-020-01087-y

Folke, C. (2006). Resilience: The Emergence of a Perspective for Social-Ecological Systems Analyses. Global Environmental Change, 16, 253-267. https://doi.org/10.1016/j.gloenvcha.2006.04.002

Galanakis, C. M. (2020). The Food Systems in the Era of the Coronavirus (CoVID-19) Pandemic Crisis. Foods, 9, 523. https://doi.org/10.3390/foods9040523

Gereffi, G. (2020). What Does the COVID-19 Pandemic Teach Us about Global Value Chains? The Case of Medical Supplies. Journal of International Business Policy, 3, 287-301. https://doi.org/10.1057/s42214-020-00062-w

Golan, M. S., Jernegan, L. H., \& Linkov, I. (2020). Trends and Applications of Resilience Analytics in Supply Chain Modeling: Systematic Literature Review in the Context of the COVID-19 Pandemic. Environment Systems and Decisions, 40, 222-243. https://doi.org/10.1007/s10669-020-09777-w

Guan, D., Wang, D., Hallegatte, S., Davis, S. J., Huo, J., Li, S. et al. (2020). Global Supply-Chain Effects of COVID-19 Control Measures. Nature Human Behaviour, 4, 577-587. https://doi.org/10.1038/s41562-020-0896-8

Hailu, G. (2020). Economic Thoughts on COVID-19 for Canadian Food Processors. Canadian Journal of Agricultural Economics, 68, 163-169. https://doi.org/10.1111/cjag.12241

Heck, S., Campos, H., Barker, I., Okello, J. J., Baral, A., Boy, E. et al. (2020). Resilient Agri-Food Systems for Nutrition amidst COVID-19: Evidence and Lessons from Food-Based Approaches to Overcome Micronutrient Deficiency and Rebuild Livelihoods after Crises. Food Security, 12, 823-830. https://doi.org/10.1007/s12571-020-01067-2

Hobbs, J. E. (2020). Food Supply Chains during the COVID-19 Pandemic. Canadian Journal of Agricultural Economics, 68, 171-176. https://doi.org/10.1111/cjag.12237

IFRC (2020a). East Africa: Red Cross Raises the Alarm over a “Triple Menace” of Floods, COVID-19 and Locusts. International Federation of Red Cross and Red Crescent Societies.

https://media.ifrc.org/ifrc/press-release/east-africa-red-cross-raises-alarm-triple-menac e-floods-covid-19-locusts

IFRC (2020b). Desert Locust Situation Update 10 December 2020. http://www.fao.org/ag/locusts/en/info/info/index.html

Ivanov, D., \& Dolgui, A. (2020). Viability of Intertwined Supply Networks: Extending the Supply Chain Resilience Angles towards Survivability. A Position Paper Motivated by COVID-19 Outbreak. International Journal of Production Research, 58, 2904-2915. https://doi.org/10.1080/00207543.2020.1750727

Kapata, N., Ihekweazu, C., Ntoumi, F., Raji, T., Chanda-Kapata, P., Mwaba, P. et al. (2020). Is Africa Prepared for Tackling the COVID-19 (SARS-CoV-2) Epidemic. Lessons from Past Outbreaks, Ongoing Pan-African Public Health Efforts, and Implications for the Future. International Journal of Infectious Diseases, 93, 233-236.

https://doi.org/10.1016/j.ijid.2020.02.049

Lal, R. (2020). Home Gardening and Urban Agriculture for Advancing Food and Nutritional Security in Response to the COVID-19 Pandemic. Food Security, 12, 871-876. https://doi.org/10.1007/s12571-020-01058-3

Lawson-Lartego, L., \& Cohen, M. J. (2020). 10 Recommendations for African Govern- 
ments to Ensure Food Security for Poor and Vulnerable Populations during COVID-19. Food Security, 12, 899-902. https://doi.org/10.1007/s12571-020-01062-7

Liu, S. (2020). Food Supply Pressure in France and Germany during COVID-19: Causes from Manufacturing. Journal of Agriculture, Food Systems, and Community Development, 9, 139-142. https://doi.org/10.5304/jafscd.2020.094.007

Me, A., \& Fu, H. (2020). How COVID-19 Is Changing the World: A Statistical Perspective. In The Committee for the Coordination of Statistical Activities (CCSA) (Vol. II). https://unstats.un.org/unsd/ccsa/

Naja, F., \& Hamadeh, R. (2020). Nutrition amid the COVID-19 Pandemic: A Multi-Level Framework for Action. European Journal of Clinical Nutrition, 74, 1117-1121. https://doi.org/10.1038/s41430-020-0634-3

OECD \& FAO (2020). OECD-FAO Agricultural Outlook 2020-2029. https://doi.org/10.1787/1112c23b-en

OECD (2020a). COVID-19 and Global Food Systems (pp. 1-7).

OECD (2020b). Food Supply Chains and COVID-19: Impacts and Policy Lessons. Comparing Crises: Great Lockdown versus Great Recession (pp. 1-11). https://doi.org/10.4060/ca8833en

Pires Ribeiro, J., \& Barbosa-Povoa, A. (2018). Supply Chain Resilience: Definitions and Quantitative Modelling Approaches-A Literature Review. Computers and Industrial Engineering, 115, 109-122. https://doi.org/10.1016/j.cie.2017.11.006

Poudel, P. B., Poudel, M. R., Gautam, A., Phuyal, S., \& Tiwari, C. K. (2020). COVID-19 and Its Global Impact on Food and Agriculture. Journal of Biology and Today's World, 9, 7-10.

Ragasa, C., \& Lambrecht, I. (2020). COVID-19 and the Food System: Setback or Opportunity for Gender Equality? Food Security, 12, 877-880.

https://doi.org/10.1007/s12571-020-01089-w

Simba, S., Niemann, W., Kotzé, T., \& Agigi, A. (2017). Supply Chain Risk Management Processes for Resilience: A Study of South African Grocery Manufacturers. Journal of Transport and Supply Chain Management, 11, 1-13.

https://doi.org/10.4102/jtscm.v11i0.325

Singh, S., Kumar, R., Panchal, R., \& Tiwari, M. K. (2020). Impact of COVID-19 on Logistics Systems and Disruptions in Food Supply Chain. International Journal of Production Research, 1-16. https://doi.org/10.1080/00207543.2020.1792000

Stephens, E. C., Martin, G., van Wijk, M., Timsina, J., \& Snow, V. (2020). Editorial: Impacts of COVID-19 on Agricultural and Food Systems Worldwide and on Progress to the Sustainable Development Goals. Agricultural Systems, 183, Article ID: 102873. https://doi.org/10.1016/j.agsy.2020.102873

Tendall, D. M., Joerin, J., Kopainsky, B., Edwards, P., Shreck, A., Le, Q. B. et al. (2015). Food System Resilience: Defining the Concept. Global Food Security, 6, 17-23. https://doi.org/10.1016/j.gfs.2015.08.001

Udmale, P., Pal, I., Szabo, S., Pramanik, M., \& Large, A. (2020). Global Food Security in the Context of COVID-19: A Scenario-Based Exploratory Analysis. Progress in Disaster Science, 7, Article ID: 100120. https://doi.org/10.1016/j.pdisas.2020.100120

United Nations (2020a). UN Policy Brief: The Impact of COVID-19 on Food Security and Nutrition (FSN) (pp. 1-8).

http://www.fao.org/policy-support/tools-and-publications/resources-details/en/c/1287 907/ 
United Nations (2020b). Policy Brief: Impact of COVID-19 in Africa Impact of COVID-19 in Africa (p. 28).

WHO (2020). WHO Coronavirus Disease (COVID-19) Dashboard. Geneva: World Health Organization. https://covid19.who.int

World Bank (2020a). Global Economic Prospects, June 2020. Washington, DC: World Bank (Issue June). https://doi.org/10.1596/978-1-4648-1553-9

World Bank (2020b). Global Economic Prospects JUNE 2020 Analytical Chapters. In $A$ World Bank Group Flagship Report (Issue June).

https://crescendoworldwide.org/wp-content/pdfnews/World bank report.pdf

World Bank Group (2020). Commodity Markets Outlook, April (pp. 1-100). Washington, DC: World Bank.

https://www.developmentaid.org/api/frontend/cms/file/2020/04/CMO-April-2020.pdf

Zimmerer, K. S., \& de Haan, S. (2020). Informal Food Chains and Agrobiodiversity Need Strengthening-Not Weakening-to Address Food Security amidst the COVID-19 Crisis in South America. Food Security, 12, 891-894.

https://doi.org/10.1007/s12571-020-01088-x 